\title{
Biogenerator for a Cocoa Farm
}

\section{Biogerador para uma Fazenda de Cacau}

Article Info:

Article history: Received 2021-11-20 / Accepted 2022-01-05/ Available online 2022-01-17

doi: 10.18540/jcecvl8iss1pp13736-01-12e

\author{
Jorge Henrique de Oliveira Sales \\ ORCID: https://orcid.org/0000-0003-1992-3748 \\ Universidade Estadual de Santa Cruz, Brazil \\ E-mail: jhosales@uesc.br \\ Rafaela Cristina Ferreira Brito \\ ORCID: https://orcid.org/0000-0002-5347-685X \\ Universidade Estadual de Santa Cruz, Brazil \\ E-mail: rcfbrito@uesc.br
}

\begin{abstract}
Biomass presents itself as a technological solution with great potential for generating energy. In this context, this work aims to develop the analysis of a rural biodigester for the production of electric energy in a cocoa farm, proposing a Marine-type model as a study reference and its production of biogas as a source of electric energy. The energy feasibility verification parameters are analyzed in relation to the energy generation system, considering a biogas load of $163 \mathrm{~m}^{3}$ per day. The technical potential for generating electricity for the chosen system suggests the supply of electricity demand with a large margin for the energy autonomy of the property.
\end{abstract}

Keywords: Biomass. Biogas. Energy Autonomy.

\section{Resumo}

A biomassa se apresenta como uma solução tecnológica de grande potencial gerador de energia. Nesse contexto, esse trabalho visa desenvolver a análise de um biodigestor rural para produção de energia elétrica em uma fazenda de cacau, propondo um modelo tipo Marinha como referência de estudo e sua produção de biogás como fonte de energia elétrica. Os parâmetros para verificação da viabilidade energética são analisados em relação ao sistema gerador de energia, considerando uma carga de biogás de $163 \mathrm{~m}^{3}$ diários. O potencial técnico de geração de energia elétrica para o sistema escolhido, sugere o suprimento da demanda de eletricidade com grande margem para a autonomia energética da propriedade.

Palavras-chave: Biomassa. Biogás. Autonomia Energética.

\section{Introduction}

Motivated by the reduction of dependence on oil exports, most countries, developed or not, have promoted actions of greater or lesser intensity so that alternative energies, with regeneration capacity for the short and medium-term, have effective participation in their energy matrices (CORTEZ et al., 2008). This is an important fact, as it contributes to reducing the consumption of petroleum products, one of those responsible for the increase in the global average temperature due to the greenhouse effect.

In this context, biomass as a technological solution has great potential power generators by the great versatility can be used to replace conventional fuel and generating electricity. This can be 
defined as "all matter of plant origin existing in nature or generated by man or animal"(SALOMON e FILHO, 2007, p. 4).

According to data from the National Energy Balance, electricity generation in Brazil using biomass as a source points out a value of 52,267 GWh for the base year 2018 (BEN, 2019). Its use can be carried out in several ways: through direct combustion, thermochemical processes (gasification, pyrolysis, liquefaction, and transesterification), or biological processes such as anaerobic digestion and fermentation (ANEEL, 2002). The main way to use this biomass is through biological conversion, carried out through anaerobic bacteria in hermetically closed environments, where methane gas $(\mathrm{CH} 4)$ is produced, the main component of biogas, together with carbon dioxide $(\mathrm{CO} 2)$ and other gases in smaller amounts.

Biogas generated from biological processes can be used in generating systems for the production of electrical energy. The most commonly used technologies are micro-turbines and internal combustion engines of the Otto cycle, that through small modifications allows the use of biogas as a fuel. Therefore, identification parameters such as flow rate are necessary, the composition and calorific value of the substrate used, and determining the real potential of electric generation and dimensioning of the biogas treatment process (BRITO, 2021).

In this context, this work aims to develop the analysis of a rural biodigester for the production of electric energy in a cocoa farm, proposing a Navy-type model as a study reference and its production of biogas as a source of electric energy.

\section{Biodigester}

The place of execution of this work is São José Farm, located in the municipality of Barro Preto, Bahia. Among the 272 hectares (ha) of rural area in the municipality. The São José Farm has 64 ha of the 272 hectares existing in the municipality, where it has a cocoa cultivation area of 36.50 ha and a pasture area of $16.93 \mathrm{ha}$, among other areas with improvements. The project will make this property the first rural unit in southern Bahia to have a biodigester for the generation of electricity.

The expectation is the construction of a Navy Model Biodigester (Figure 1), with a batch process discontinuous, with the capacity to supply the population average energy consumption and reuse waste, generating more savings and less environmental impact.

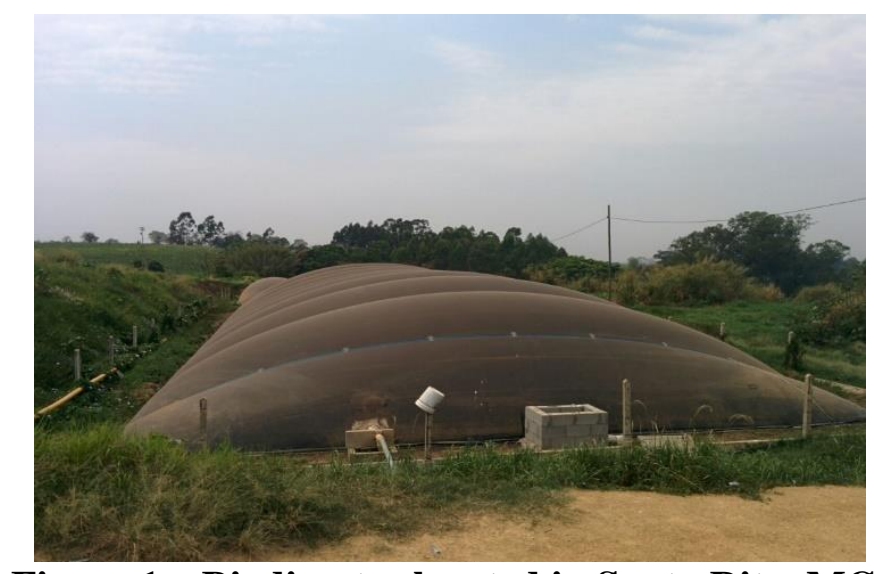

Figure 1 - Biodigester located in Santa Rita, MG.

The material available to be used as a substrate in the anaerobic digestion inside the biodigester has organic residues generated by the rural population of the property and vegetable residues generated by agricultural activities of cocoa cultivation, creation of animals, benefaction, and others from the same source.

Biogas production and biodigester sizing depend on the accessible space for construction, the amount of substrate, and the type of organic matter available on the rural property where the project 
will be applied. Thus, the calculation of the daily load volume becomes necessary, in order to estimate the volume $\left(V_{B}\right)$ of the biodigester (JUNQUEIRA, 2014).

For the case of São José Farm, the object of the study, it is considered that the projected biodigester is capable of receiving the volume of organic waste produced daily by the average of 200 people who live or work on the farm, added to the contributions of the load of animal waste from cattle raising and plant residues such as cocoa husks.

For the application context, cocoa husk has interesting properties for the fermentation process, such as its high calorific value, around $2500 \mathrm{kcal} / \mathrm{kg}$, and faster fermentation at room temperature, when compared to residues such as cattle manure and another vegetable origin (CARDOSO et al., 2002; HARWOOD, 1980). This residue represents $80 \%$ of the cocoa fruit and its total amount is calculated from the monthly average productivity of cocoa arroba per hectare, generated in the Farm. Considering variable productivity in the range of 200 to 400 arrobas per hectare, different values are obtained for the mass of cocoa husk available on the property. Cocoa nut has been modeled to obtain physical data (SALES, 2021).

Daily productivity values are obtained by dividing the amount of cocoa husk mass by 30 days. This bark is crushed and mixed with water at the rate of $1 \mathrm{ton} / \mathrm{m}^{3}$, using as a reference the same proportion used by the biodigester built by CEPLAC in 1979. This study can be replicated for the cupuassu case (CUNHA, 2021).

The daily volumes found are added to all available substrate contributions (fixed contributions of cattle waste and domestic sewage per inhabitant), obtaining the total daily load volumes, which vary according to the amount of cocoa husk used, as shown in Table 1.

Table 1 - Volume and types of available waste.

Waste

Total daily load volume available $\left(\mathbf{m}^{3} /\right.$ day $)$

\begin{tabular}{cccc}
\hline $\begin{array}{c}\text { Cattle } \\
\text { Production }\end{array}$ & $\begin{array}{c}\text { Domestic } \\
\text { sewage/hab. }\end{array}$ & cocoa husk & \\
2,60 & 18,40 & 0 & 21 \\
2,60 & 18,40 & 2,92 & 23,92 \\
2,60 & 18,40 & 4,38 & 25,38 \\
2,60 & 18,40 & 5,84 & 26,84 \\
\hline
\end{tabular}

Source: Brito, 2021.

With the available load volume, the volume $\left(V_{B}\right)$ of the biodigester can be calculated as a function of this daily volume $\left(V_{C}\right)$ and the hydraulic retention period $\left(T_{R H}\right)$ necessary for the degradation of organic matter through anaerobic bacteria (OLIVEIRA, 2009). This is done through the relationship:

$V_{B}=V_{C} \times T_{R H}$

The hydraulic retention time will also be given depending on the type of organic matter available, especially those of animal origin, as they have a longer degradation time. With an average period of 35 days for cattle/swine, 45 days for goat/sheep, and 60 days for poultry litter (OLIVER, 2008).

The inbox dimensions will be based on the result of this formulation so that it is able to support the daily load volume in the operation. While for the outbox, the sizing is done for a volume of at least three times the volume of the daily load, so that the bio-fertilizer produced is stored (JUNQUEIRA, 2014). 
With these results, it is reasonable to estimate the possible volumes for the biodigester (Table 2), according to Equation 1, considering a hydraulic retention period of 35 days and the variation in the daily load that was shown in table 1 .

Table 2 - Volume estimate for the biodigester as a function of daily load variation

\begin{tabular}{cc}
\hline $\boldsymbol{V}_{\boldsymbol{C}}$ & $\boldsymbol{V}_{\boldsymbol{B}}$ \\
\hline Total daily load volume available $/ \mathbf{~ m}^{\mathbf{3}} / \mathbf{d a y}$ & Biodigester volume/ $\mathbf{~ m}^{\mathbf{3}}$ \\
21 & 735 \\
23,92 & 837,2 \\
25,38 & 888,3 \\
26,84 & 939,4 \\
\hline
\end{tabular}

The volume variation considered gives us an average of approximately $850 \mathrm{~m}^{3}$ for the biodigester, which corresponds to around $34 \%$ of the volume of a $2500 \mathrm{~m}^{3}$ Olympic swimming pool. Due to the high storage capacity required for the fermentation chamber, the Navy's biodigester model becomes the most suitable model, as it can handle a high flow of waste and has a low implementation and maintenance cost compared to other types.

It is considered that the volume is composed of specified external dimensions of $20 \times 17 \mathrm{~m}$, depth $2.5 \mathrm{~m}$ (Figure 2), being covered by flexible geomembrane (gas meter) of polyvinyl chloride (PVC). Thus, the construction is carried out on a continuous direct foundation, which requires the initial services of earth-moving and excavation, in addition to the PVC pipes responsible for conducting the inflow and outflow of waste in the biodigester and for transporting the biogas.

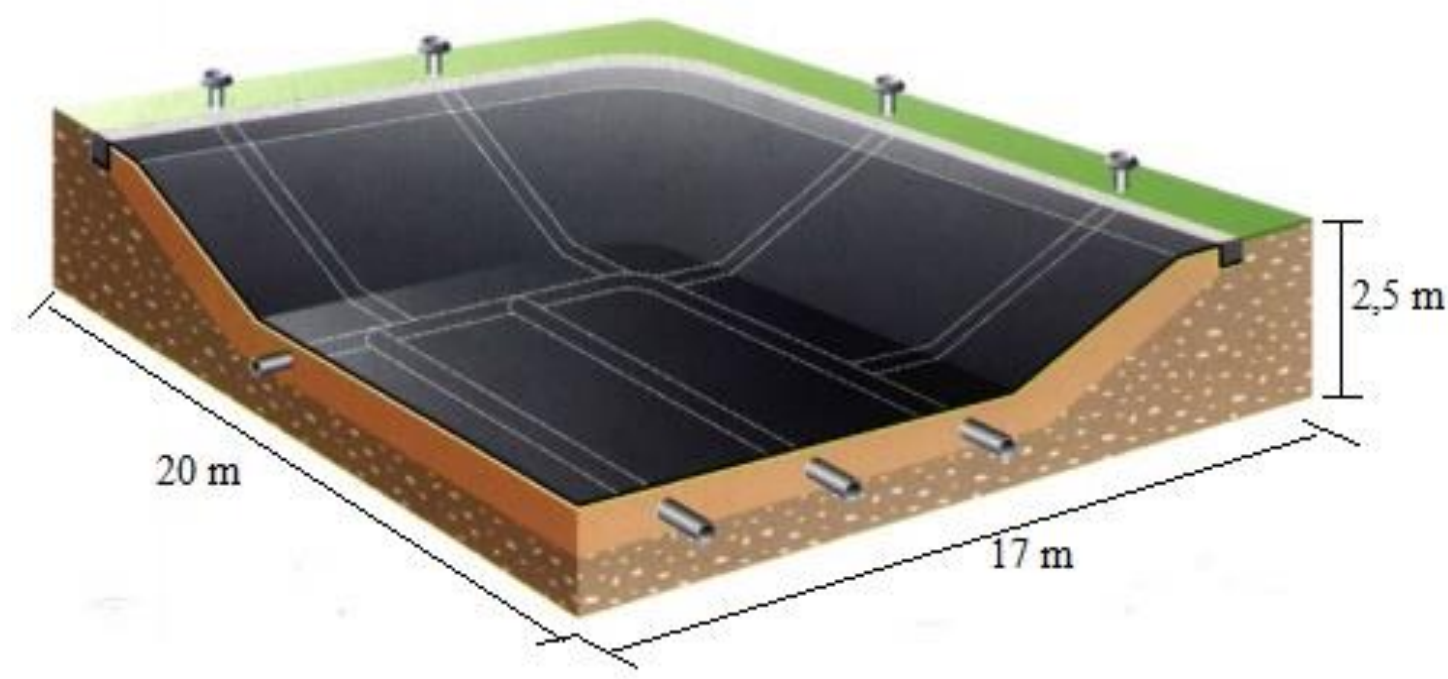

Figure 2 - Estimated dimensions for the Navy model biodigester.

It is important to emphasize that the exact dimensions of the project can only be defined based on the evaluation of other parameters. These parameters can be evaluated in productive terms for designating the correct dimensions of the biodigester and its electricity generating system. 


\section{Generating System}

Internal combustion engines are widely used because they can operate with different types of fuels, both liquid and gaseous. The engine's combustion chamber and the combustion process itself are integrated into its overall operation. For its simplicity, robustness and high power/weight ratio represent the technology most widespread among heat engines, causing triggers are employed on a large scale as propulsion elements to generate continuous electricity and the flexibility that allows them to be the most equipment used for burning biogas (SALOMON, 2007).

For the use of biogas as a fuel for electricity generation, the most used primary machines are internal combustion engines (MCI) (SOUZA, 2016). They are engines that work through spark ignition (Figure 3), based on the Otto thermodynamic cycle, with 4 operating times - admission, compression, combustion and exhaust - where the electricity generators are coupled in the energy conversion process.

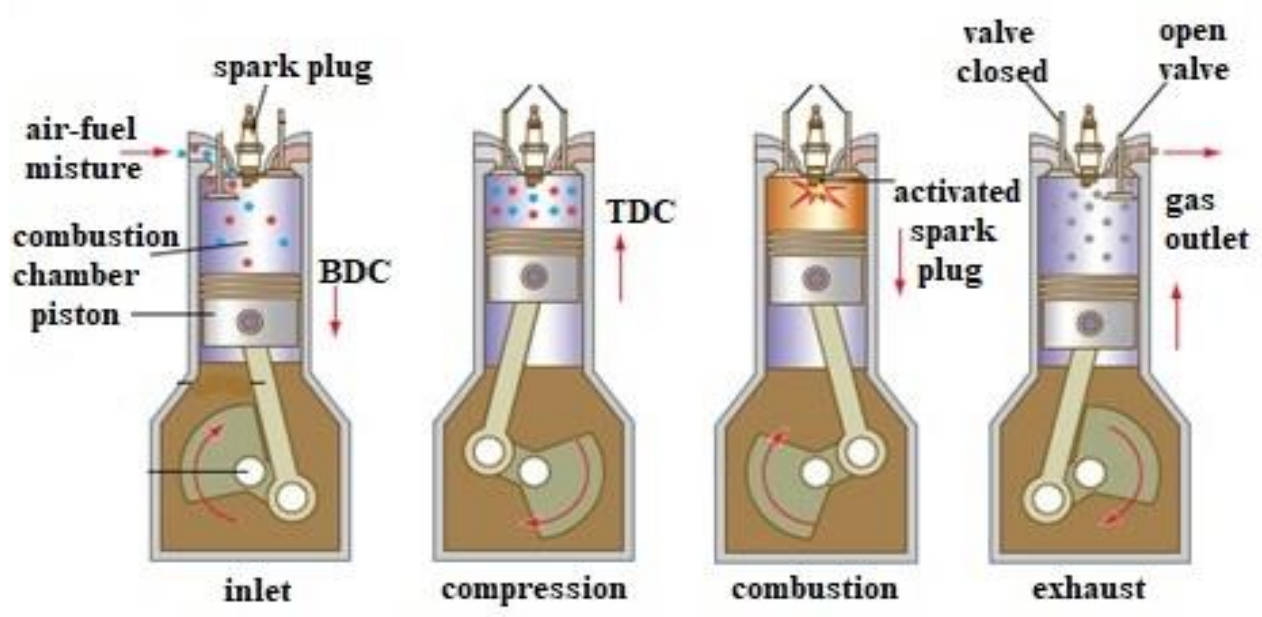

Figure 3. Four stroke mechanical cycle of an internal combustion engine. Source: Adapted from Encyclopedia Britannica.

Although Diesel cycle engines also operate with biogas, Otto cycle engines have advantages in relation to the ease of adaptation of these machines. As Otto cycle engines are already designed to work through spark ignition in an air-fuel mixture, the basic modification occurs in the supply of this mixture to the carburetor, using biogas as fuel (SUZUKI, 2011).

The carburetor is one of the components of internal combustion engines, for the production of air-fuel mixture that is compressed by the piston, combusted to contact the spark of the spark plug. Feeding the engine with the fuel gas (biogas) normally uses a carburetor type "venturi" (Figure 4 and 5). This type of carburetor modifies the flow velocity of the air stream (by narrowing its crosssection), causing a pressure drop in the venturi, according to Bernoulli's principle. The gaseous fuel is then dosed through a flow regulating valve and mixed in the main air stream, in a proportion required for the engine to work uniformly (SOUZA, 2006).

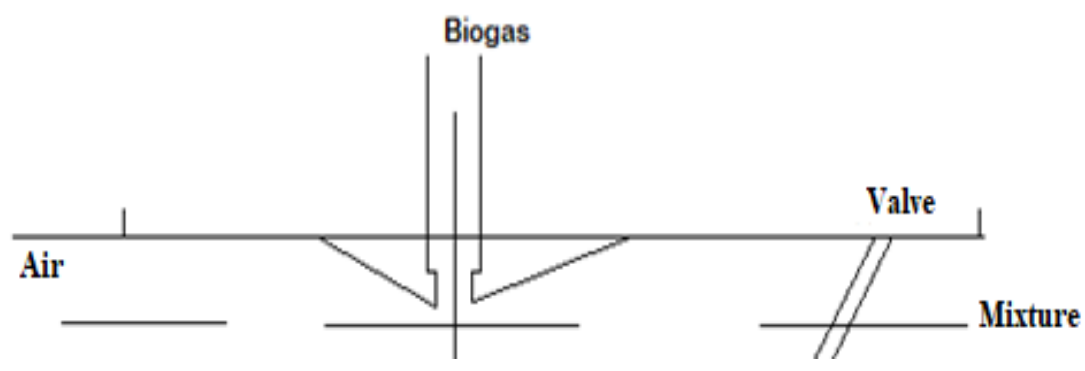

Figure 4 - Air-fuel mixing process in a venturi carburetor.

Source: Own authorship. 


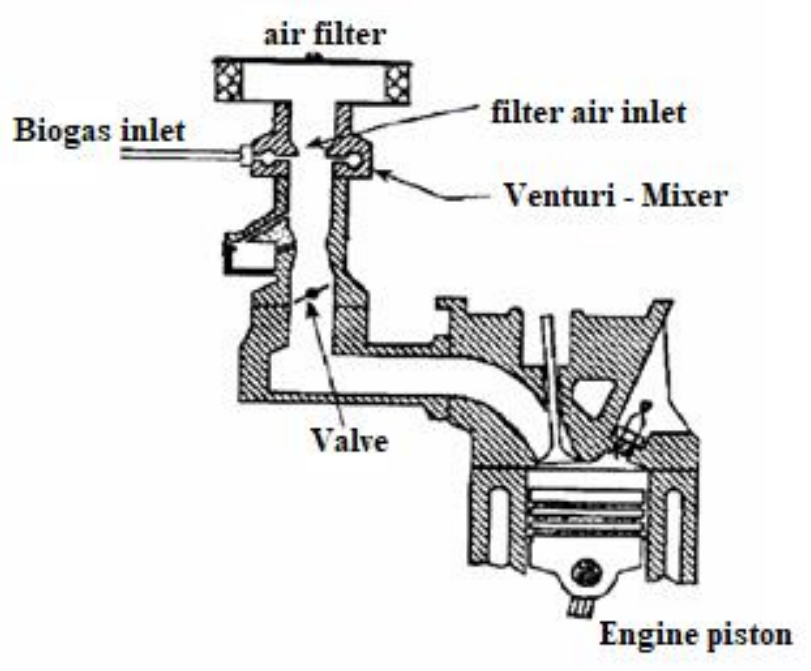

Figure 5 - Mixing system in a gas engine. Source: SOUZA, 2016.

The mixture proceeds from the carburetor to the intake valve, where it is drawn in by the downward movement of the piston, from the top dead center (TDC) to the bottom dead center (BDC). In the second half, the piston moves from the BDC to the TDC, compression occurring and starting of the ignition, by means of an electric spark, just before the piston completes the stroke.

In the third time, the piston in downward movement causes the expansion of gasses, with energy transfer to the piston. At this instant, the energy moves in an upward motion, from the BDC to the TDC, causing the exhaust gasses to exit into the atmosphere (SOUZA, 2006).

Compression-ignition diesel engines can be adapted for the use of biogas in bi-fuel operation, also injecting pilot fuel (diesel), or in operation only on biogas. Starting with the second case, for this to happen, they need to be ottolized, which is, converted to the Otto cycle through more complex adaptations, which involve the introduction of a carburetor and a spark ignition system, and reduction in the compression ratio. Note: as adaptations are complex, other movements may also arise, needing to be aware of the changes that may occur. (SUZUKI, 2011).

\section{Biogas Electricity Generating Engines}

The biogas produced in the biodigester is used in a generator engine to produce heat and electricity. For this, the motor is coupled to the electrical generator, able to transform secondary engine mechanical energy into electrical voltages different depending on the used type of threephase connection.

The coupling of the engine to the generator can be done through gear ratio, pulleys, belts or direct coupling. The absorbed mechanical energy of the motor shaft is transformed into electrical energy, with all working in synchronous speed, a coupling efficiency of $90 \%$, considered for design purposes (SOUZA, 2016).

The electric power generation system involves auxiliary components, in addition to the internal combustion engine and the electricity generator. Mention may be made among them, the engine rotational speed controller, the control system of the air-fuel mixture by controlling the passage of formation of biogas and stoichiometric mixture; starting system, providing the starting current needed, in addition to exhaust systems, cooling, ventilation, control panel, among other components.

Currently, most biogas generator engines available on the market have powers ranging from $50 \mathrm{~kW}$ to $2000 \mathrm{~kW}$ (SOUZA, 2016). Some companies stand out for the commercialization of biogas 
generator sets, which can be related to the required application according to the specifications of the set. Table 3 shows some of these specifications for manufacturers of biogas generator engines.

Table 3 - Specifications of biogas generator engines.

\begin{tabular}{|c|c|c|c|c|c|c|c|c|c|c|c|c|}
\hline \multirow{3}{*}{$\begin{array}{c}\text { Manufacturer } \\
\text { Model }\end{array}$} & \multicolumn{2}{|c|}{$\begin{array}{c}\text { GE- } \\
\text { Jerbacher }\end{array}$} & \multicolumn{2}{|c|}{ Caterpillar } & \multicolumn{2}{|c|}{ Leão Energia } & \multicolumn{2}{|c|}{ Biogás Motores } & \multicolumn{2}{|c|}{ Cummins } & \multicolumn{2}{|c|}{$\begin{array}{c}\text { CHP } \\
\text { Brasil }\end{array}$} \\
\hline & & JMC & & & & & & & & & & \\
\hline & $\begin{array}{l}\text { JIVS } \\
\text { B.LC }\end{array}$ & $\begin{array}{l}420 \\
\text { GS- } \\
\text { B. L }\end{array}$ & G3406 & G3520 & LGG70 & LGG120 & $\begin{array}{l}\mathrm{CM} \\
366\end{array}$ & GGB 140 & $\begin{array}{c}\text { C1750N6C } \\
\text { LTU }\end{array}$ & $\begin{array}{c}\text { C2000N6C } \\
\text { LBTU }\end{array}$ & $\begin{array}{r}\text { CHP } \\
150\end{array}$ & $\begin{array}{l}\text { CHP } \\
200\end{array}$ \\
\hline Power $(\mathrm{kW})$ & 330 & 1413 & 155 & 1600 & 50 & 100 & 50 & 92 & 1750 & 2000 & 96 & 115 \\
\hline $\begin{array}{c}\text { Biogas } \\
\text { consumption } \\
\left(\mathrm{m}^{3} / \mathrm{h}\right)\end{array}$ & - & - & $\begin{array}{l}62,2 \\
(75 \% \\
\text { load })\end{array}$ & $\begin{array}{c}647(75 \% \\
\text { load })\end{array}$ & 30 & 50 & - & - & - & - & - & - \\
\hline Generator & - & - & $\begin{array}{c}\text { Self } \\
\text { excited } \\
4 \text { poles }\end{array}$ & $\begin{array}{c}\text { Permanent } \\
\text { magnet } 6 \\
\text { poles }\end{array}$ & $\begin{array}{c}\text { Cramacho } \\
4 \text { poles }\end{array}$ & $\begin{array}{c}\text { Cramacho } \\
4 \text { poles }\end{array}$ & 4 poles & $\begin{array}{c}\text { Alternator } \\
\text { Web } 4 \\
\text { poles }\end{array}$ & - & - & - & - \\
\hline $\begin{array}{l}\text { Rotation } \\
\text { (RPM) }\end{array}$ & 1800 & 1200 & 1800 & 1200 & 1800 & 1800 & 1800 & 1800 & 1500 & 1514 & - & - \\
\hline Voltage (V) & - & - & 220 & 480 & $220 / 380$ & $220 / 380$ & $220 / 380$ & - & - & - & - & - \\
\hline
\end{tabular}

Source: SOUZA (2016), CATERPILLAR, LEÃO, BIOGÁS, CUMMINS, CHP (2020).

Some of the manufacturers listed in Table 3 were contacted and provided information regarding the availability of their equipment for the required biogas demand. Mostly, because they work with higher power engines, which they considered not necessary for this project, the produced biogas load was considered insufficient to feed their engines. However, the Brazilian company Leão Energia was able to meet the design requirements necessary for this application and provide information and specifications for efficiency and costs, which will be examined below.

\section{Generating System Analysis}

To choose the electricity generation system, it is necessary to take into account the dimensional parameters of the equipment, which involve the efficiency of the generator motor, the time of use of the generation plant and the daily availability of biogas together with its calorific value. From these data, it is possible to quantify the electric energy generated per cubic meter of biogas, according to Equation (2) (SOUZA, 2016):

$P_{T E}=P_{C I} \cdot B_{d}$

Where $P_{T E}\left(\mathrm{kWh} /\right.$ day) is the theoretical potential of electricity production, $P_{C I}\left(\mathrm{kWh} / \mathrm{m}^{3}\right)$ is the lower calorific value of biogas and, $B_{d}$ is the daily production of biogas $\left(\mathrm{m}^{3} /\right.$ day). Numerically Simulating the biogas production as a function of time, based on the availability of waste to the biodigester and analytical data of this case study, we obtain the results of Figure 6. 


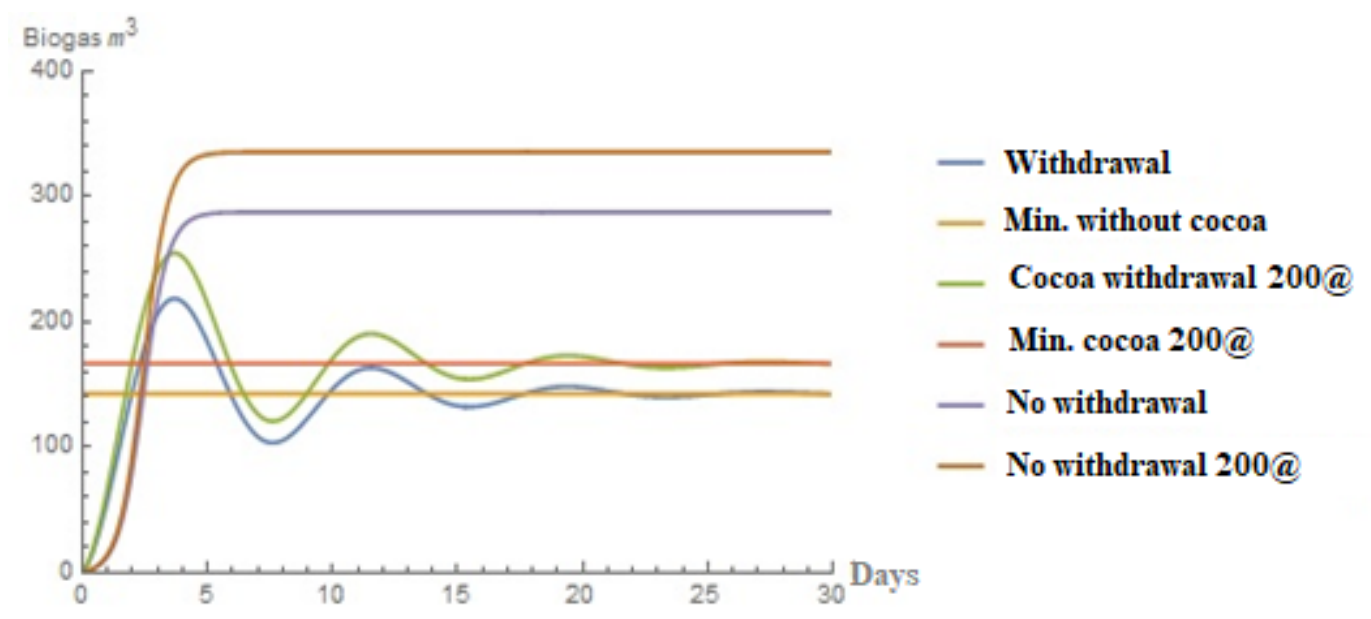

Figure 6 - Biogas production over time in cases with and without biogas removal.

The graph in figure 5 reveals a better optimization of the system for the case with biogas removal using cocoa as an input, which achieves stability (green curve) around $163 \mathrm{~m}^{3}$ (BRITO, 2021). This value considers the minimum production limit line for two hundred arrobas of cocoa husk, where the volume of biogas converges in this case.

For calculating the potential for electric power generation, it takes into account that this volume is available daily to be used to feed the carburetor and consequently the internal combustion engine. This dosage is carried out through the flow regulating valve, present in the carburetor, and the commands issued by the biodigester's electronic monitoring system.

In view of the daily demand for biogas estimated and considering an operating system for seven hours a day, the Lion generator LPG45 model of the company Leão Energia was selected through a quotation held in November 2020. The specifications of the group generator are shown in Table 4.

Tabela 4 - Lion LPG45 Generator Set Specifications

$\begin{array}{cc}\text { Continuous Power } & 45 \mathrm{~kW} / 56 \mathrm{kVA} \\ \text { Voltage } & 220 / 127 \mathrm{~V} \\ \text { Nominal Frequency } & 60 \mathrm{~Hz} \\ \text { Electrical Efficiency } & 34 \% \\ \text { Power Factor } & 0,8 \\ \text { Fuel consumption } & 22 \mathrm{Nm}^{3} / \mathrm{h}\end{array}$

N- Refers to standard conditions for temperature and pressure (STP).

Source: Leão Energia (2020).

The system used by the company has an FPT brand engine, Model N45 SM6, Turbocharged, $1,800 \mathrm{rpm}$, volume of 4.5 liters, Otto cycle (4 strokes), 4 cylinders in line, electric starter and 24 Vec starter (Volts in direct current), in addition to liquid cooling with radiator, fan and centrifugal pump. The alternator used for power generation is WEG brand, three-phase, brush-less (powered by inverters), 4 poles, hard disk, special for deforming loads and with electronic voltage regulator.

Based on this information, it is possible to determine the theoretical potential for electricity production, introduced in Equation (2), considering the lower calorific value $\left(P_{C I}\right)$ of biogas directly proportional to the concentration of methane present, based on Table 5. 
Table 5 - Specific weight and calorific value of biogas as a function of chemical composition

\begin{tabular}{ccc}
\hline $\begin{array}{c}\text { Chemical composition of } \\
\text { biogas }\end{array}$ & Specific weight $\left(\mathbf{k g} / \mathbf{m}^{\mathbf{3}}\right)$ & PCI (kcal/kg) \\
\hline $10 \% \mathrm{CH}_{4}$ e $90 \% \mathrm{CO}_{2}$ & 1,8393 & 465,43 \\
$40 \% \mathrm{CH}_{4}$ e $60 \% \mathrm{CO}_{2}$ & 1,46 & $2.333,85$ \\
$60 \% \mathrm{CH}_{4}$ e $40 \% \mathrm{CO}_{2}$ & 1,2143 & $4.229,98$ \\
$65 \% \mathrm{CH}_{4}$ e $35 \% \mathrm{CO}_{2}$ & 1,1518 & $4.831,14$ \\
$75 \% \mathrm{CH}_{4}$ e $25 \% \mathrm{CO}_{2}$ & 1,0268 & $6.253,01$ \\
$95 \% \mathrm{CH}_{4}$ e $5 \% \mathrm{CO}_{2}$ & 0,7768 & $10.469,6$ \\
$99 \% \mathrm{CH}_{4}$ e $1 \% \mathrm{CO}_{2}$ & 0,7268 & $11.661,02$ \\
\hline
\end{tabular}

Source: Adapted from IANNICELLI, 2008.

Thus, an optimized production system with a calorific value referring to the concentration of $60 \%$ of methane and $40 \%$ of carbon dioxide is assumed. For the transformation from kcal to $\mathrm{kW}$, the conversion factor of 0.001163 is used (SANTOS, 2017). Then, the theoretical amount of electrical energy generated per cubic meter of biogas can be verified, introducing the term referring to the consumption of biogas specified by the manufacturer in Table 4, according to Equation (2):

$P_{T E}=\left(4.229,98 \frac{\mathrm{kcal}}{\mathrm{kg}}\right)\left(1,163 \cdot 10^{-3} \mathrm{~kW}\right)\left(1,2143 \frac{\mathrm{kg}}{\mathrm{m}^{3}}\right)\left(22 \mathrm{~m}^{3} / \mathrm{h}\right)$

The theoretical calculation gives the approximate potential of $131.42 \mathrm{kWh}$. However, for more realistic data concerning the electricity production capacity, it is necessary to estimate a technical potential for electricity production (Equation 3), which takes into account the possible losses suffered by the system through the global efficiency of conversion of the thermal and electrical machines used, which is also specified in Table 4, with $=34 \%$ (SOUZA, 2016; SANTOS 2017). Then,

$P_{T e c}=\frac{P_{T E} \cdot \eta}{100}$

Replacing the values found, we get a technical electricity production potential of around 44.7 $\mathrm{kWh}$. In addition to the electrical project, which should be defined in accordance with the norms of the local energy concessionaire, the electricity generation system with a biogas generator engine must meet the conditions of frequency, power, voltage regulation and temperature at the installation site. According to the results obtained from Equation 3, the generator system must have an electric power generation based on the calculated potential technical $(44.7 \mathrm{kWh})$. In addition, must be considered a minimum inductive power factor of, for three-phase nominal voltage and continuous operating regime, according to standardized conditions of mechanical and electrical balance (SOUZA, 2016). Thus, the generating power of the plant can be estimated through Equation (4), obtaining the approximate electrical potential of $56 \mathrm{kWh}$.

$P_{G}=\frac{P_{T e c}}{\cos \varphi}$ 
Seeking to supply the energy load required by the analyzed location, the study of the equipment to be used in this task must be carried out in line with the analysis of the annual history of electricity consumption of the São José farm (where the study is applied) and from the required power values calculated in this section.

Therefore, it is considered the consumption period from November 2019 to November 2020 according to the variation shown in the graph of Figure 6.

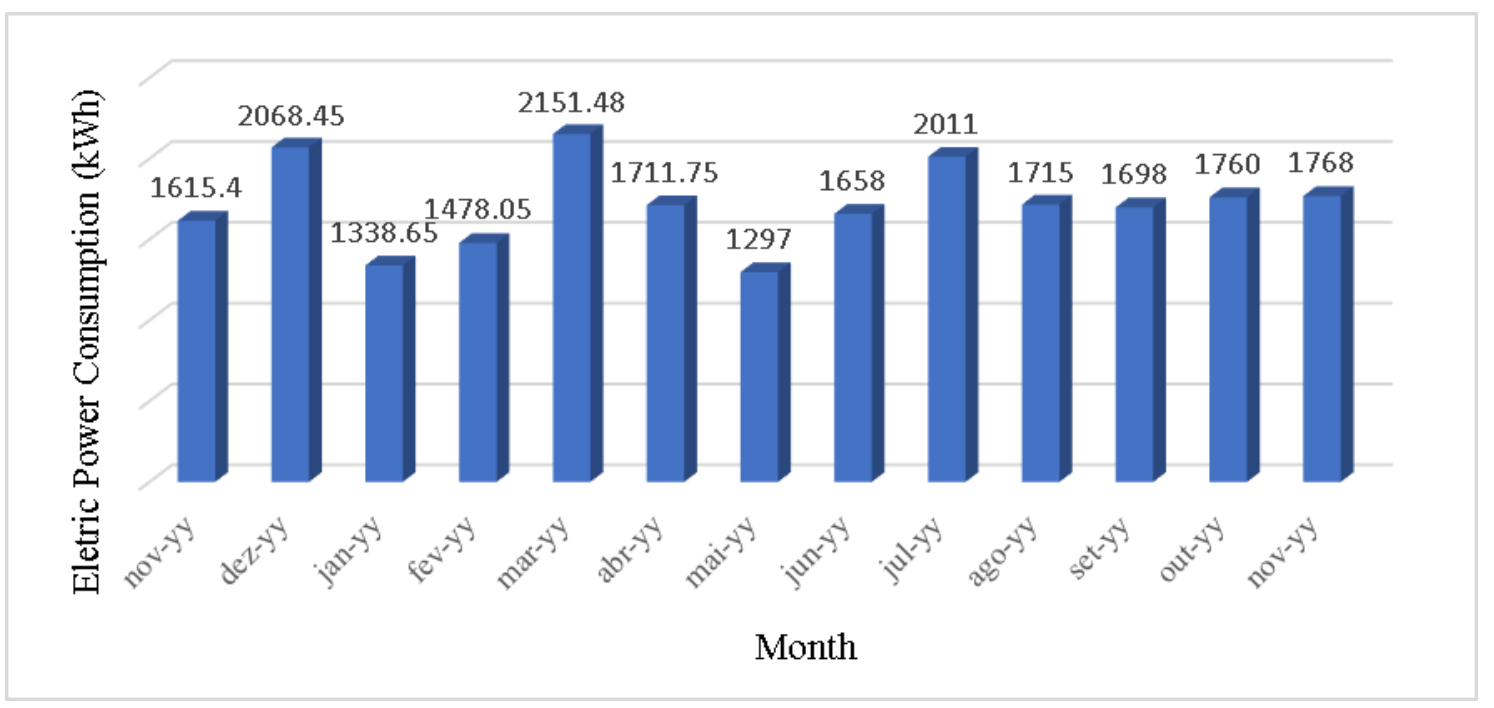

Figure 6 - Electricity consumption at São José Farm - Barro Preto/BA.

Source: Adapted from COELBA, 2020.

Analysis of Farm electricity bills shows the variation in energy consumption over the months, with an average around $1713 \mathrm{kWh}$ per month. In this way, it is possible to compare the values of consumption and electric generation potential calculated for the system, in order to verify the supply of energy demand required by the location in question.

Starting from the assumption terms of a system that operates at about 7 hours per day, based on Equation (4), we have the potential to generate $390 \mathrm{kWh}$ daily $\left(P_{G} \times 7=390\right)$. Except for Sundays and holidays, you get an average of 26 days per month operation and 312 days of operation per year.

Thus, you can check a technical potential for electricity generation of approximately 10,165 $\mathrm{kWh}$ per month (multiplying the potential of $390 \mathrm{kWh}$ daily for 26 days period). This amount exceeds by almost six times the value of the local average monthly consumption load and indicates the possible energy feasibility for the system. Thus, it can then be made a deeper economic analysis in terms of cost and time of use of equipment, to verify its efficiency and economic viability of the full undertaken.

\section{Final considerations}

The analyzed case allows an overview of verification of the viability of energy autonomy with the use of biogas. The biomass available for this conversion has been found through animal waste, persons present at the property and different yields for cocoa farming, generating cocoa husks as waste, with a potential interesting energy for the fermentation process. The changes in the initial operating conditions of the biodigester system concerned the amount of available waste cause direct changes in the system's dimension and, consequently, in the relationship between the production of biogas and electricity.

Thus, in this manner in terms of efficiency productive the power scaling analysis of the electricity generating system already shows promising results, indicating an effective supply of energy demand in the studied locality, with a generation of the technical potential of the plant six 
times higher than the demand consumption in the period analyzed. It is clear that the use of the tools of analysis and simulation checked here are essential for correct sizing and decision making that considers the technical criteria and subsequently economic feasibility criteria, as well as other possible modeling parameters to be inserted in the future.

\section{Acknowledgments}

The authors appreciate the financial support from FAPESB/BOL 0034/2020 and CNPq.

\section{References}

Agência Nacional De Energia Elétrica - ANEEL. (2002). Atlas de Energia Elétrica do Brasil. Brasília, 2002. 153 p.

Balanço Energético Nacional (BEN): Ano base 2018. Empresa de Pesquisa Energética - EPE (Brasil). Rio de Janeiro: Ministério de Minas e Energia. 2019. Anual.

Brito, R. C. F. (2021). Modelagem de um Biogerador tipo Marinha para Análise de viabilidade de Autonomia Energética em uma Fazenda de Cacau. Dissertação de Mestrado, Universidade Estadual de Santa Cruz, Ilhéus, BA, Brasil.

Cardoso, S. A. et al. (2002). Utilização de Resíduos de Cacau para Produção de Energia no Estado do Pará. Universidade Federal do Pará. In: Procedings of the 4th Encontro de Energia no Meio Rural, Campinas, SP, Brasil [online]. Disponível em: http://www.proceedings.scielo.br/scielo.php?pid=MSC0000000022002000200066\&script=sci artte $\underline{x t \& t \operatorname{lng}=p t}$

Ceplac. (2012). Aproveitamento dos Subprodutos, Derivados e Resíduos do Cacau. In: III Congresso Brasileiro do Cacau: Inovação Tecnológica e Sustentabilidade, Ilhéus, 43 slides.

Coelba. Portal de serviços: Histórico de Consumo. Disponível em: http://servicos.coelba.com.br/Pages/index.aspx. Acesso em: mai. 2020.

Cortez L. A. B. et. al. (2008). Biomassa no Brasil e no Mundo. In: CORTEZ L. A. B. et. al Biomassa para Energia. Campinas: Editora UNICAMP, cap. 1, p. 15-18.

Cunha, E. S, et. al. (2021). Determination of thermophysical properties of cupuassu (Theobroma grandiflorum) dry almonds. The Journal of Engineering and Exact Sciences - jCEC, Vol. 07 N. 02.

Encyclopædia Britannica. Motor de Combustão Interna. Disponível em: https://educacaoautomotiva.com/2017/07/06/motor-4-tempos-como-funciona/. Acesso em: jun. 2020.

Harwood, J. H. Instituto Nacional de Pesquisas da Amazônia (1980). Pesquisas para a produção de biogás na Amazônia. Acta Amazonica [online], 10(2), 403-409. https://doi.org/10.1590/180943921980102403

Iannicelli, A. L. (2008). Reaproveitamento Energético do Biogás de uma Indústria Cervejeira. Dissertação de Mestrado, Universidade de Taubaté, Taubaté, SP, Brasil.

Junqueira, S. L. C. D. (2014). Geração de Energia através de biogás proveniente de esterco bovino: Estudo de Caso na Fazenda Aterrado. Graduação, Escola Politécnica da Universidade Federal do Rio de Janeiro, Rio de Janeiro, RJ, Brasil.

Oliveira, D. R. (2009). Geração de Energia Elétrica a partir do Biogás Produzido pela Fermentação Anaeróbica de Dejetos em Abatedouros e as Possibilidades no Mercado de Carbono. Trabalho de Conclusão de Curso, Escola de Engenharia de São Carlos, Universidade de São Paulo, São Carlos, SP, Brasil.

Oliver, A. P. M., et al. (2008). Manual de Treinamento em Biodigestão. Brasil: Instituto Winrok, 2008. 23 p.

Sales, J. H., Suzuki, A. T. (2021). Thermal Ellipsoidal model of Cocoa almond. Brazilian Journal of Development, Curitiba, v.7, n.3, p. 31618-31633.

Sales, J. H. O.; Lima, G. P. A. (2020). Procedimento didático para a modelagem computacional da amêndoa do cupuaçu em coordenadas cartesianas. Revista Brasileira de Ensino de Ciência e Tecnologia, Ponta Grossa, v.13, n. 3, p. 1-19. 
Salomon, K. R. (2007). Avaliação Técnico-Econômica e Ambiental da Utilização do Biogás Proveniente da Biodigestão da Vinhaça em Tecnologias para Geração de Eletricidade. Tese de Doutorado, Universidade Federal de Itajubá, Itajubá, MG, Brasil.

Salomon, K. R \& Filho, G. L. T. (Org.). (2007). Série Energias Renováveis: Biomassa. Itajubá: Centro Nacional de Referência em Pequenas Centrais Hidrelétricas - CERPCH.

Santos, P. A. dos. (2017). Potencial Teórico e Técnico de Geração de Energia a partir de Biomassa e Fotovoltaica para o Estado de São Paulo. Dissertação de Mestrado, Faculdade de Engenharia Elétrica e de Computação, Universidade Estadual de Campinas, Campinas, SP, Brasil.

Souza, R. G. de. (2006). Desempenho do Conjunto Motogerador Adaptado a Biogás. Dissertação de Mestrado, Universidade Federal de Lavras, Lavras, MG, Brasil.

Souza, S. N. M. de. (2016). Manual de Geração de Energia Elétrica através de Biogás no meio rural. Universidade Estadual do Oeste do Paraná, Cascavel, PR, Brasil.

Suzuki, A. B. P. (2011). Uso de biogás em motores de combustão interna. Revista Brasileira de Tecnologia Aplicada nas Ciências Agrárias [online], 4(1), e-ISSN 1984-7548, 221-237. https://revistas.unicentro.br/index.php/repaa/article/viewFile/1405/1487 